\title{
Detection of circulating prostate cancer cells via prostate specific membrane antigen by chronoimpedimetric aptasensor
}

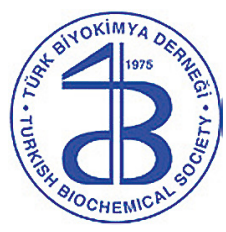

\section{Kronoimpedimetrik aptasensör ile prostat spesifik membran antijeni aracılığıyla dolaşımdaki prostat kanseri hücrelerinin tespiti}

https://doi.org/10.1515/tjb-2021-0056

Received March 13, 2021; accepted May 15, 2021;

published online June 9, 2021

\section{Abstract}

Objectives: Sensitive and accurate techniques for early detection of prostate cancer, which has a good chance for successful treatment if detected early, are of utmost value. Our aim is to develop a sensitive chronoimpedimetric biosensor for detection of circulating prostatic tumor cells (CTCs) with an aptamer selective for prostate specific membrane antigen (PSMA).

Methods: Thiolated PSMA-specific aptamer was immobilized on the gold nanoparticle modified carbon screen-printed electrodes. After characterization with cyclic voltammetry and electrochemical impedance spectrometry, scanning electron microscopy and atomic force microscopy studies were conducted to confirm the modifications. LNCaP cells (androgen-sensitive human prostate adenocarcinoma cells), were then added to the serum samples and chronoimpedimetric detection of CTCs in samples were performed.

Results: Our study showed one cell detection capability in real serum samples with a linear range from 1 to 40 cells/ $\mathrm{mL}$. The incubation time was $130 \mathrm{~s}$. LOD was found to be

\footnotetext{
*Corresponding author: Zihni Onur Uygun, Department of Medical Biochemistry, Faculty of Medicine, Kafkas University, 36100, Kars, Turkey, E-mail: onur_uygun@hotmail.com. https://orcid.org/00000001-9045-7271

Ferhan Girgin Sağin, Department of Medical Biochemistry, Faculty of Medicine, Ege University, Bornova, İzmir, Turkey. https://orcid.org/ 0000-0003-1309-6788
}

0.62 cells $/ \mathrm{mL}$ and relative standard deviations were lower than 2\% RSD. Reproducibility tests indicated a regression coefficient as $R^{2}=0.9963 \pm 0.0178$.

Conclusions: This new biosensor enables rapid, accurate, precise, reproducible and highly sensitive detection of PSMA on CTCs in prostate cancer and paves the way to new diagnostic applications and research-based studies.

Keywords: aptasensor; chronoimpedance; CTC; liquid biopsy; prostate cancer; PSMA.

\section{Öz}

Amaç: Prostat kanserinin erken tanısında tedavi başarısı oldukça yüksek olup erken tanıda kullanılacak hassas ve spesifik tekniklere gereksinim sürmektedir. Bu çalışmadaki amacımız da, dolaşımdaki prostat kanser hücrelerinin (CTCs) üzerindeki prostat spesifik menbran antijenine (PSMA) yönelik bir aptamer kullanarak bu hücreleri tespit eden hassas bir impedimetrik biyosensör sistemi geliştirmektir.

Gereç ve Yöntem: Çalışmada, androjene hassas prostat adenokarsinom hücre hattı olan LNCaP hücreleri kullanılmıştır. Bu hücrelerdeki PSMA için seçici olan spesifik bir tiyollü aptamer, altın nanopartiküllerle modifiye edilmiş karbon screen-printed elektrotlar üzerine immobilize edilmiştir. Siklik voltametri ve elektrokimyasal impedans spektrometri karakterizasyonlarında sonra görsel olarak taramalı elektron mikroskopu ve atomic kuvvet mikroskopuyla modifikasyonlar tanımlanmıștır. Ardından LNCaP hücrelerinin eklendiği serum örneklerinde kronoimpedimetrik ölçümler gerçekleştirilmiş ve optimizasyon çalışmaları yapılmıştır.

Bulgular: Çalışmamız, gerçek serum örneklerinde, systemin mL'de 1 ila 40 hücre arasında doğrusal bir aralık ile bir 
hücre algılama kapasitesini göstermiştir. İnkübasyon süresi 130 sn olarak tespit edilmiş, LOD 0,62 hücre/mL olarak hesaplanmış ve biyosensörün rölatif standard deviasyonu $\%$ 2'den daha düşük olarak bulunmuştur. Tekrarlanabilirlik testlerinde regresyon katsayıs1 $\mathrm{R}^{2}=0.9963 \pm 0.0178$ 'dir.

Sonuç: $\mathrm{Bu}$ yeni impedimetrik biyosensör hızlı, doğru, tekrarlanabilir ve yüksek derecede duyarlı bir şekilde prostat kanserinde CTC üzerindeki PSMA ölçümünü gerçekleştirmiş olup yeni tanısal uygulamaların ve araştırma temelli klinik çalışmaların önünü açmaya aday sonuçlar sunmaktadir.

Anahtar kelimeler: aptasensör; kronoimpedans; PSMA; CTC; sıvı biyopsi; prostat kanseri.

\section{Introduction}

According to the clonal theory of evolution, first put forward by Nowell in 1976 [1], the emergence and progression of a tumor generally depends on the genetic changes and imbalance, especially somatic mutations, in the original clone [2]. Clonal evolution plays an important role not only in the development of the tumor but also in its progression through metastasis. Ruiz et al. detected common disorders (deletion/amplification) and noncommon genomic changes in the biopsy samples taken from the primary tumor (pancreatic tumor) and the organs where this tumor spread (diaphragm, lung, liver) [3]. This shows that clonal evolution continues in tumor cells even in the case of metastasis development and explains the resistance to treatment. In fact, cell supply via tissue biopsies for the purpose of determining the morphological and/or genetic/epigenetic characteristics of malignant cells in cancer diagnosis and treatment is often invasive, non-reproducible, costly, time-consuming and carries high risk of morbidity [4]. On the other hand, blood biomarkers cannot be effective to detect cancer because of the specificity and sensitivity problems.

The main mechanism for the development of distant metastases in the cancer process is via hematological spread and analysis of tumours using biomarkers circulating in blood samples of cancer patients is considered to be a desirable approach in detecting systemic tumor cell spread [5]. Thus, the ability to detect and characterize tumours in such a minimally invasive and repeatable way is a hot topic in cancer research. The two most well-developed biomarkers detected by liquid biopsy are circulating tumour cells (CTCs) and circulating cell-free tumour DNA (ctDNA) however both are subject to technical variability in the preanalytical and analytical steps.
Analysis of CTCs which result from the primary tumor or metastases has great benefit in early detection of invasive cancer and in guiding the treatment of advanced cancer cases. A study conducted with the CellSearch System (Veridex LLC, Warren, NJ, USA), which allows automated enrichment and immunohistochemical determination of CTCs in peripheral blood of metastatic breast cancer cases showed the importance of CTCs in these patients [6]. In addition, CTCs also have been shown to provide unique opportunities to create visual samples for morphological identification of intact cells, provide information about the metastatic process, functional studies, and broader information such as DNA, RNA and proteinbased molecular profiling [7]. Numerous studies showed the relationship between the number of CTCs and the severity of the disease (cancer burden of the body, advanced stage).

Although CTC isolation techniques have been improved with the complex technologies developed in recent years, CTC identification and characterization still remains to be technically challenging. CTCs are in the background of millions of blood cells, thus detecting these low concentrations of a tumor cell in the circulation is not an easy task. In particular, patients with early stage cancer have extremely low concentrations of CTC, so highly sensitive and specific analytical methods, elaborate and complex concentrating steps, and larger blood volume are needed for CTC determination [7].

The most widely used techniques for CTC detection and isolation use antibodies to selectively bind cell surface antigens, thus are immune-based. Tumor cells express different cell surface markers than blood cells and therefore can be separated from the circulatory cells. The multistep protocols for multiple binding events and amplification tags in these labeled assays increase specificity and sensitivity, however they also increase the assay complexity. Label-free assays, on the other hand, allow quantitative real-time measurement, yet they are challenged with complex matrices in which non-specific bindings and extra signals may be detected.

CTC's are non-electroactive, however, it is possible to use electrochemical impedance spectroscopy (EIS) which provides an electrode-electrolyte interface and electrode binding kinetics to the analyte, which is important for affinity based biosensors [8]. EIS is an effective and sensitive [9] technique that can provide label-free [10] detection of non-electroactive molecules. By using EIS, it is easy to measure electrode surface electron transfer resistance, which is formed by electrochemical reaction of a redox probe, to obtain electrode surface characteristics by simulating an electrode circuit model [11]. 
Thus, we aimed to develop a biosensor for detecting CTCs in prostate cancer by using EIS as the detection method. Our target was the cell surface antigens, namely prostate specific membrane antigen (PSMA) in prostate cancer CTCs. PSMA is a catalytic membrane protein located on prostate tissues. It does not exist in circulation normally, but it is increased in prostate cancer and shed into the blood. It is also used for PET scanning for precise cancer cell detection in tissues [12] because of its sensitivity in prostate cancer. In order to directly target PSMA and CTCs where they are located, we developed an aptamerbased impedimetric CTC biosensor system. With this approach, here we present a technique that enables early detection of CTCs in prostate cancer in a highly sensitive, cost-effective and fast way.

\section{Materials and method}

\section{Materials}

Prostate cancer cells (LNCaP clone FGC (ATCC ${ }^{\circledR}$ CRL-1740 ${ }^{\mathrm{TM}}$ )) were obtained from ATCC (U.K.). Other consumable chemicals were obtained from Merck (U.S.A.). Gold nanoparticle screen printed electrodes were obtained from Dropsens (DRP-110GNP, Dropsens, Spain). Palmsens 3 Potentiostate was used for electrochemical analysis (Pamsens B.V. Netherlands).

\section{Sample collection and cell culture}

Ege University Scientific Research Ethics Committee approved the study with the decision number of 20-9T/61. Accordingly, blood samples were collected from healthy individuals and used directly without storage and in case diluted by using physiological serum $(0.9 \% \mathrm{NaCl})$. Prostate cancer cells (LNCaP clone FGC (ATCC $^{\circledR}$ CRL-1740 ${ }^{\mathrm{TM}}$ )) were obtained from ATCC (U.K.) and cultured at $37^{\circ} \mathrm{C}$ (5\% $\mathrm{CO}_{2}$, dissolved in medium containing $10 \%$ fetal calf serum, aliquoted at $20 \mu \mathrm{L}$ (160 Cells). Until they grow up at 8,000 cells/mL, they were stored at $-80^{\circ} \mathrm{C}$. Other consumables were obtained from Merck (U.S.A.). The dissolution process was carried out by adding cells that reached room temperature directly to blood samples taken from healthy individuals.

\section{Biosensor development and characterization}

Screen printed gold nanoparticle electrodes (GNPE) were used to prepare the biosensor system as transducer. Before the electrodes were modified, electrodes were washed by double distilled water. Afterwards, cyclic voltammetry (CV) and EIS were performed to obtain baseline signals in $\mathrm{pH}=7.50 \mathrm{mM}$ phosphate buffer containing $5 \mathrm{mM} \mathrm{Fe}(\mathrm{CN})_{6}^{3-/ 4-}$ and $100 \mathrm{mM} \mathrm{KCl}$ as redox probe. $\mathrm{CV}$ was performed at a scanning rate of $100 \mathrm{mV} / \mathrm{s}$ by applying between -0.2 and $0.5 \mathrm{~V}$ potentials. EIS performing parameters were $180 \mathrm{mV}$ DC and $10 \mathrm{mV}$ AC potential between 10,000 and $0.05 \mathrm{~Hz}$ frequency scan. After the baseline performance and washing with pure water, the electrodes were dried under nitrogen gas flow. Subsequently, the dried electrodes were modified using the aptamer sequence of PSMA located on the LNCaP cell surface. For this modification, $10 \mathrm{mmol}$ Aptamer sequence, which was dissolved in DNase and RNAase-free water (GGAGGACGAUGCGGAUCAGCCAUGUUUACGUCACUCUUCUACCUCGUCHUCUUUUUUACGUCACUCU- this residue has been modified with $\mathrm{SH}$ ) was firstly immobilized on GNPE via thiol-Au groups as self-assembly monolayer (SAM). The SAM formation was incubated at $+4{ }^{\circ} \mathrm{C}$ for overnight to prevent DNase activity to distrupt aptamer sequences, and SAMs were formed between the gold-sulphur bond (Au-S-Aptamer bond). Afterwards, the stock LNCaP cells were dropped directly onto the electrode. CV and EIS measurements were also confirmed by scanning electron microscopy (SEM) and atomic force microscopy (AFM). Then, the biosensor was immersed in a serum containing LNCaP cells at a concentration of $1 \mathrm{cell} / \mathrm{mL}$ in a total of $3 \mathrm{~mL}$ measurement cell, and the time dependent impedance measurement (Chronoimpedance, $\mathrm{CI}$ ) was performed at a single frequency After LNCaP measurement time was determined, optimization processes were started. In these, the cells are added to the real serum samples and the linear measurement range of the LNCaP cell, the lowest measurement limit (LOD), the lowest determination concentration (LOQ), repeatability and the reproducibility tests of the calibration curves have been performed. Calibration curves were performed by fitting impedance curves to a proper circuit model [11].

\section{Results and discussion}

CTCs detection is not only important for the early diagnosis of cancer but also for the earlier evaluation of cancer metastasis, recurrence and chemotherapeutic efficacy. The CellSearch $^{\circledR}$ (Veridex, Raritan, NJ) which uses antibodies to detect the CTCs in the blood, is the first U.S. food and drug administration (FDA) approved product. However, it has considerable limitations such as expensive equipment, high detection costs of samples, complicated enrichment steps, long detection times, and low sensitivity and selectivity.

In this study, a new approach for detecting CTCs is used. Our target CTCs were LNCaP cells and the target molecules were the PSMA on these cells. A chronoimpedimetric biosensor capable of high sensitivity detection of PSMA, shown to be a reliable biomarker for prostate cancer CTCs, has been developed using gold nanoparticles modified with aptamers.

For the last decades, electrochemical biosensors provide a promising approach for simple, rapid, sensitive and selective, cost-effective analysis in many biological materials. While label-based technologies are often mostly costly and time consuming, label free sensors do not carry these disadvantages and can be integrated into lab on-achip platform. Thus, we established a label-free approach with the use of aptamers, which are single stranded nucleotide sequences produced using high throughput 
automated screening processes. These small molecules have many advantages compared to antibodies. They are efficient capture agents and exhibit high specificity towards their targets. Aptamers possess higher structural and storage stability and their biocompatibility for immobilization on different surfaces are remarkable. In one of the studies using these molecules, anti-PSMA aptamer was immobilized over poly (methylmethacrylate) substrate for detection of CTCs in a high throughput micro-sampling device [13].

Aptamers were also the capturing molecules in our new biosensor system and they were immobilized on gold nanoparticles to the electrode surface via $\mathrm{Au}-\mathrm{SH}$ bond. The reason for using the gold nanoparticle electrode was because of the available distance between these particles which facilitated aptamer's conformational changes. Aptamer molecules were immobilized on gold nanoparticles and their conformational changes were facilitated so that the detection of attached cells to the aptamer surface was much easier. This affinity-based binding was measured by CV and EIS in redox probe. The CV and EIS results of the electrode modified with GNPE, aptamer bound GNPE (GNPE-Apt) and LNCaP coupled with aptamer (GNPE-Apt-LNCaP) are given in Figure 1A, B.

According to the data seen in Figure 1A, 1B, the LNCaP biosensor has been successfully modified. Figure $1 \mathrm{~A}$ shows a decrease in CV peak currents with the modifications created on the electrode surface. This indicates that there are aptamer bonds on the surface. EIS data also shows that there is surface binding and this is proven by the increase in surface electron transfer resistance due to the increase in impedance values. LNCaP cell binding was also confirmed.

These modifications are visualized in Figure 2 which shows the SEM and AFM images of the modification steps. In Figure 2A, gold nanoparticles are brightly seen on the gold nanoparticle coated electrode and LNCaP cells are seen in Figure 2B, respectively (Figure 2A, B). When the morphological structure was examined, AFM images (Figure 2C, D) also showed the difference between the gold nanoparticle electrode and the LNCaP bonded electrode by the increased thickness of the electrode (Figure 2A-D).

After the modification steps, chronoimpedimetric measurement was carried out in real serum samples to find out the time needed for attachment of LNCaP cells to the surface. Accordingly, the impedance curve (10 cells $/ \mathrm{mL}$ ) obtained in the modification steps was used and the CI frequency was determined. The point where the phase angle remained constant and the impedance increased was selected and the CI measurement was performed (Figure 3). GNPE-Apt electrodes were soaked in $1 \mathrm{cell} / \mathrm{mL}$ LNCaP
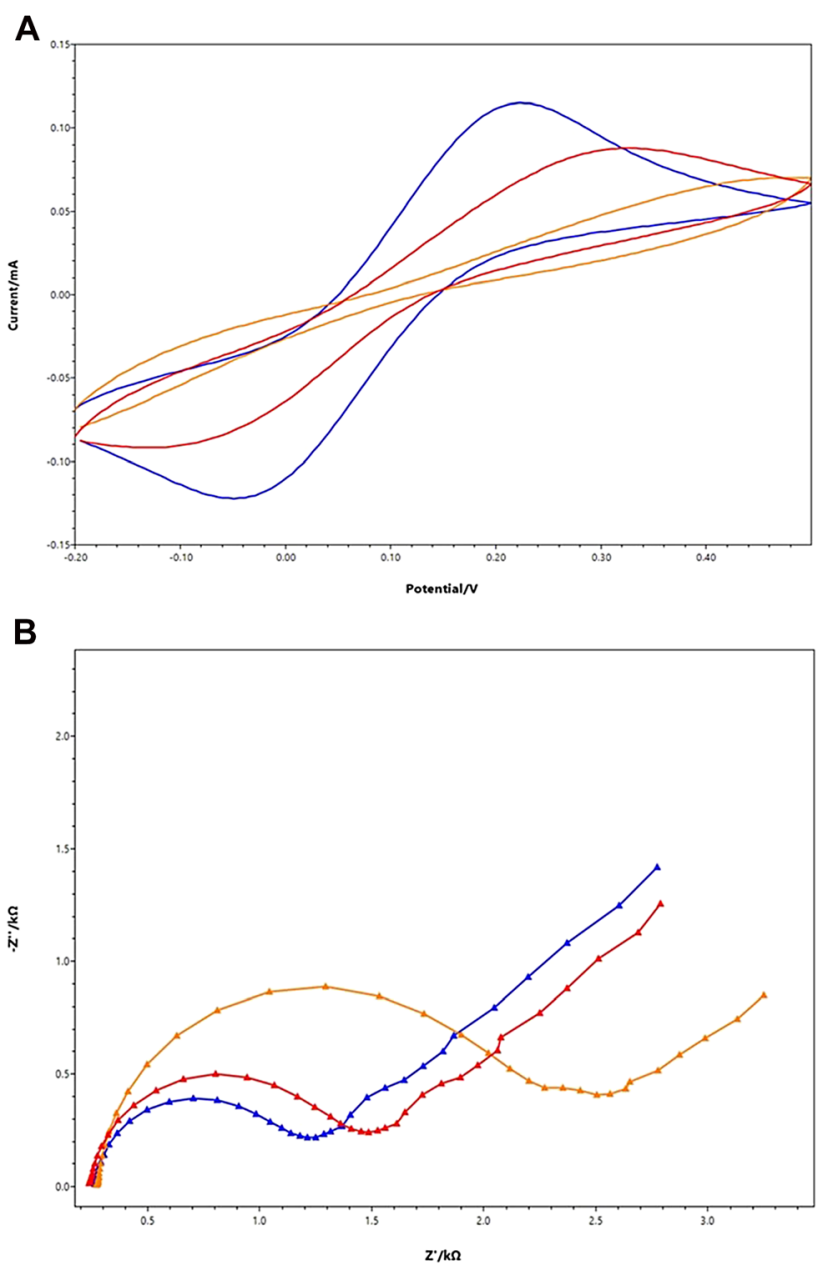

Figure 1: CV and EIS data showing the modification steps of the LNCaP biosensor.

A. Representation of the CV data (Blue CV; GNPE, Red CV; GNPE-Apt, Orange CV; GNPE-Apt-LNCaP modifications) at different scan cycles. B. Representation of EIS data (Blue EIS; GNPE, Red EIS; GNPE-Apt, Orange EIS; GNPE-Apt-LNCaP (LNCaP: 10 cells $/ \mathrm{mL}$ ) at different scan cycles.

serum sample. As seen in Figure 3, the maximum rate of increase of the LNCaP cell continued for $130 \mathrm{~s}$. Accordingly, LNCaP cell measurement time optimization was determined as $130 \mathrm{~s}$ and this duration is used for the standard chart. The increase over time indicates the change in PSMA concentration on the cell surface.

The standard graphic is drawn based on the data obtained during $130 \mathrm{~s}$ of measurement. Using the Randless circuit model, based on the characteristics of the impedance curves shown in Figure 3, impedance and resistance values of the calibration curve are calculated (Figure 4). The impedance change obtained with $\mathrm{CI}$ is approximately $50 \Omega$. Accordingly, it correlates with the impedance 

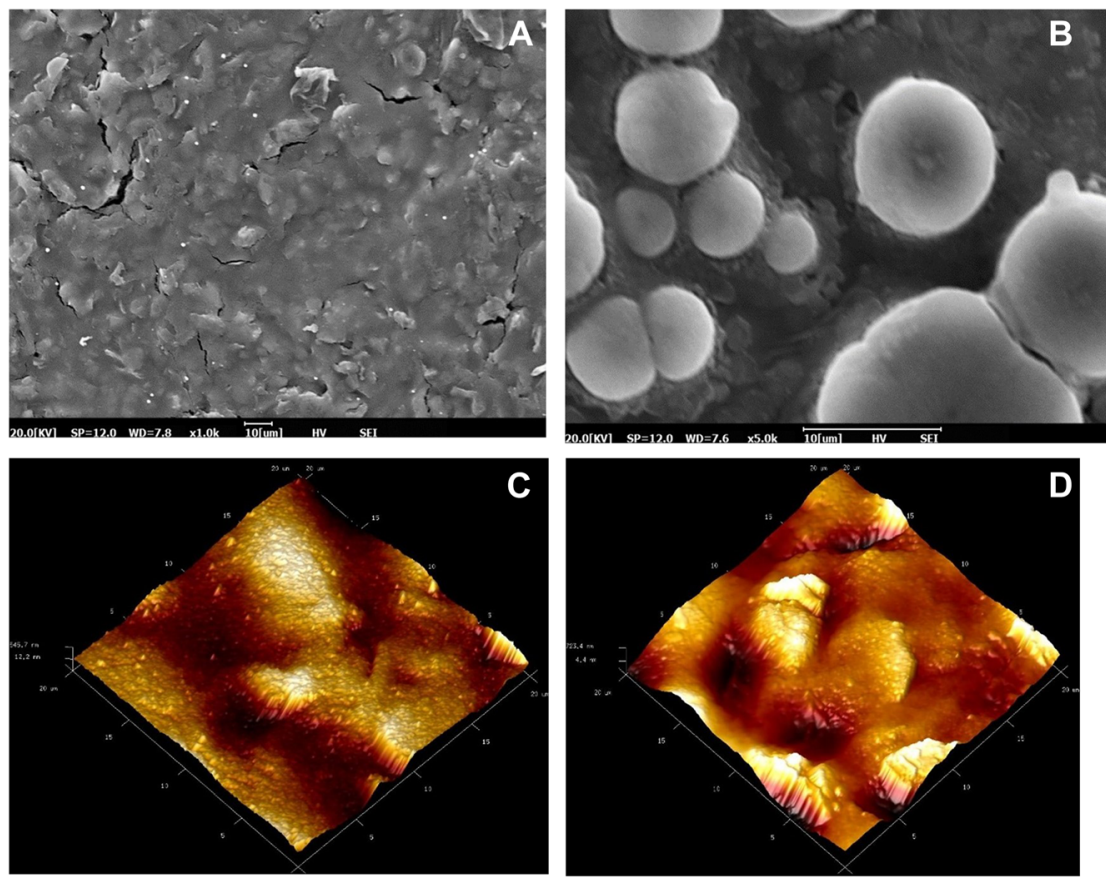

Figure 2: SEM and AFM images of LNCaP biosensor indicate successful modification steps.

A. SEM images of GNPE, B. SEM images of GNPE-Apt-LNCaP modification, C. AFM images of GNPE, D. AFM images of GNPE-Apt-LNCaP modification.

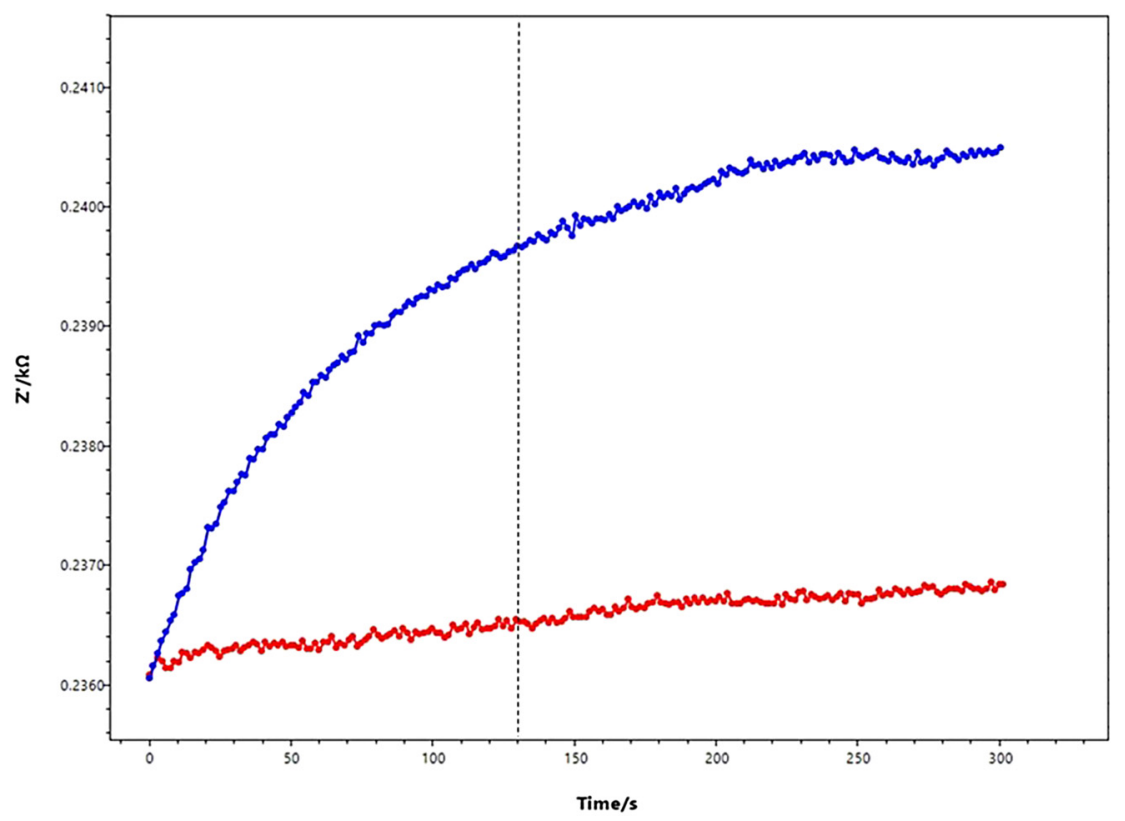

Figure 3: Chronoimpedance measurement of the LNCaP biosensor. (Red display is GNPE-Apt biosensor in serum, Blue display is GNPE-Apt biosensor at a concentration of $1 \mathrm{cell} / \mathrm{mL}$ LNCaP). The optimum measurement time is found to be $130 \mathrm{~s}$.

obtained after $130 \mathrm{~s}$ of incubation of $1 \mathrm{cell} / \mathrm{mL}$ concentration. This shows the accuracy of the system.

When the impedance data obtained from Figure 4 are pointed against cell number values, the calibration curve was formed (Figure 5).

As seen in Figure 5, the biosensor offers a linear measurement with the regression coefficient as 0.996. This indicates that the system provides accurate measurement between 1 and 40 cells $/ \mathrm{mL}$.
In the optimization steps of the biosensor, a standard concentration of 10 cells $/ \mathrm{mL}$ was added to the real serum samples and triple measurements were conducted. The standard deviation of the impedance measurements was calculated as 16.58. A LOD value of 0.62 cells $/ \mathrm{mL}$ was obtained by dividing the standard deviation by 3.3 times the slope of the calibration curve. According to this theoretical value, at least 620 cells can be detected in $1 \mathrm{~L}$ of blood. Likewise, the baseline value of the theoretical 

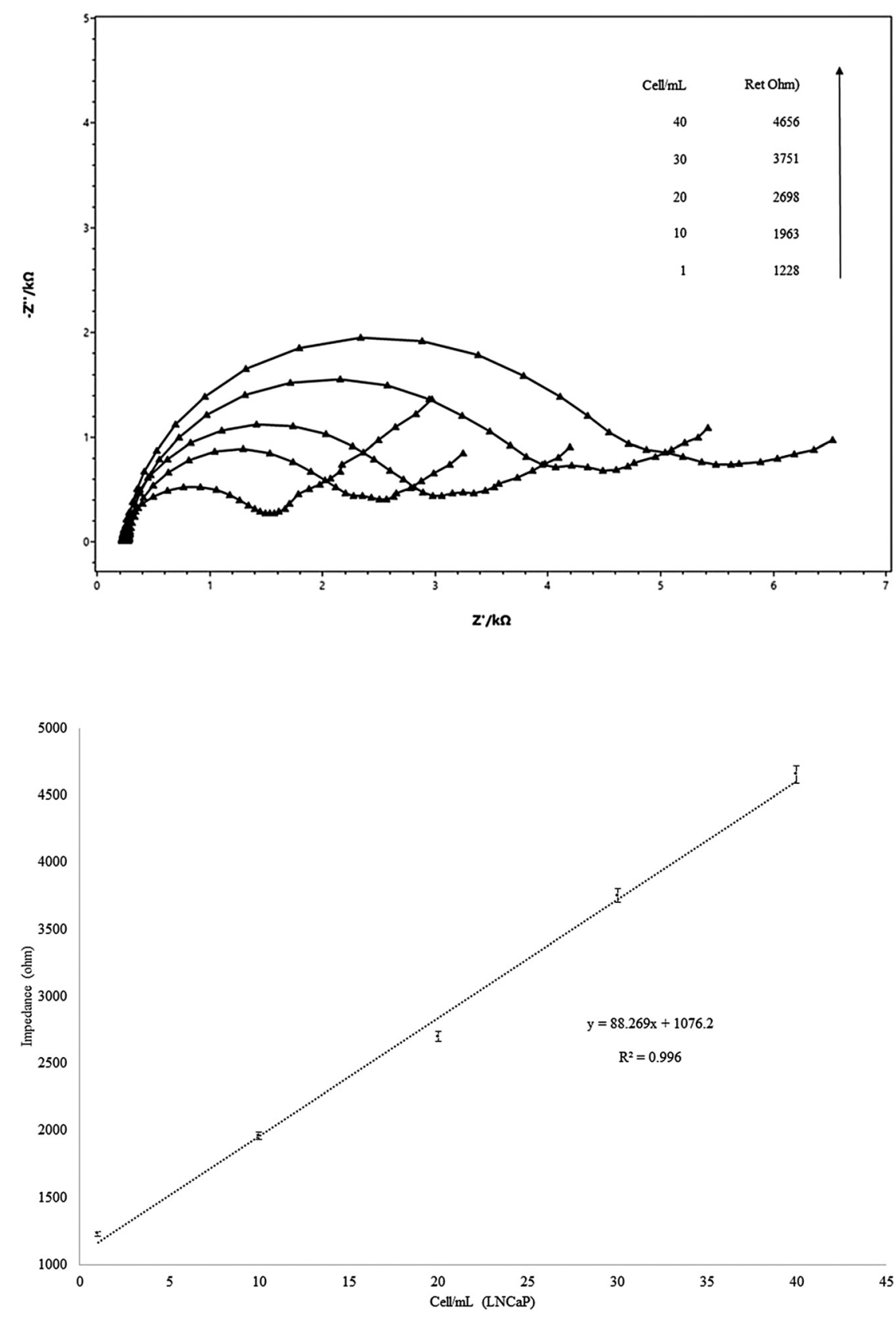

Figure 4: EIS representation of the standard graph of the LNCaP biosensor between 1 and 40 cells $/ \mathrm{mL}$.
Figure 5: Calibration curve of $\mathrm{LNCaP}$ biosensor where $y$ is impedance and $x$ is cell $/ \mathrm{mL}$ concentration $(y=88.269+1,076.2)$. calibration curve was calculated by multiplying the standard deviation by 10 and dividing it to the slope of the calibration curve and LOQ value was found as 1.87, which is close to the starting point of the calibration curve.

In the repeatability tests, the cells were added to real blood samples, which includes blood cells and LNCaP cells 10 and 40 cells $/ \mathrm{mL}$ in different samples. The measurements were repeated 3 times for each concentration and the relative standard deviations (RSD) were calculated as $0.995 \%$ for 10 cells $/ \mathrm{mL}$ concentration and $1.434 \%$ for 40 cells/mL concentration.
Reproducibility was also tested by preparing the calibration curve five times, and regression coefficient was calculated as $\mathrm{R}^{2}=0.9963 \pm 0.0178$.

All these data indicate that the newly developed biosensor system has several advantages. First of all, using the gold nanoparticles in our system facilitated aptamer conformational change and prevented cell-cell interaction, and that is confirmed with the related SEM pictures. The distance between gold nanoparticles has also increased the sensitivity and selectivity by increasing the distance and movement of aptamers from each other. Secondly, 
the aptamer based chronoimpedimetric detection enabled us detect CTCs in a more specific, sensitive and fast way compared with other studies [14]. The most important step in biosensor systems is to obtain the optimum time to measure the analyte concentration. One of the biggest advantages of our chronoimpedimetric study is that it was able to provide measurement in a short time. While most cell-based biosensor systems require at least $30 \mathrm{~min}$ to determine the amount of cells in the sample [13], chronoimpedimetric analysis enabled us to test the target concentration in seconds.

After the optimization studies, our proposed biosensor exhibited good analytical performance for detection of PSMA with an excellent linear range and low detection limit. In short, this new biosensor enables rapid, accurate, precise, reproducible and highly sensitive detection of PSMA on CTCs in prostate cancer and opens the possibilities for diagnostic applications and research-based real time studies.

\section{Conclusion}

Despite all the advances in CTC detection technologies and their diverse capture and enrichment systems, many significant challenges are yet to be met, particularly those with respect to analytical and clinical sensitivities. Antigen-free approaches indicate a lot of potential for clinical application success as they overcome the challenge of heterogeneous manifestation of expressed membrane proteins in CTCs. Our study reports the development of a new chronoimpedimetric biosensor system that enables the detection of $\mathrm{LNCaP}$ cells via PSMA binding with aptamer. This new method has high reproducibility and provides a fast and accurate measurement. Since the prostatic fluid passes the cancer cells and RNA to the urine through the urethra, one future area can be the application of this biosensor system to detect the genetic and cellular information in the urine, to provide clues about the presence of prostate cancer. Adopting such tools into routine clinical practice will demand laborious studies not only in the analytical validity, but also in clinical validity and utility. These tools, coupled with bioinformatics tools and annotated databases, will provide evidence as to whether detected genomic aberrations in blood may aid in predicting the most suitable cancer therapy on a personalized level.
Conflict of interest: Authors have no conflict of interest. Çıkar çatışması: Yazarlar arasında çıkar çatışması yoktur.

\section{References}

1. Nowell PC. The clonal evolution of tumor cell populations. Science 1976;194:23-8.

2. Marusyk A, Polyak K. Tumor heterogeneity: causes and consequences. Biochim Biophys Acta Rev Canc 2010;1805: 105-17.

3. Ruiz C, Lenkiewicz E, Evers L, Holley T, Robeson A, Kiefer J, et al. Advancing a clinically relevant perspective of the clonal nature of cancer. Proc Natl Acad Sci USA 2011;108:12054-9.

4. Bettegowda C, Sausen M, Leary RJ, Kinde I, Wang Y, Agrawal N, et al. Detection of circulating tumor DNA in early- and late-stage human malignancies. Sci Trans 2014;6:224ra24.

5. Schwarzenbach H, Pantel K. Circulating DNA as biomarker in breast cancer. Breast Cancer Res 2015;17:136.

6. Cristofanilli M, Budd GT, Ellis MJ, Stopeck A, Matera J, Miller MC, et al. Presence of circulating tumor cells (CTC) in metastatic breast cancer (MBC) predicts rapid progression and poor prognosis. J Clin Oncol 2005;23:524.

7. Banys M, Müller V, Melcher C, Aktas B, Kasimir-Bauer S, Hagenbeck $C$, et al. Circulating tumor cells in breast cancer. Clin Chim Acta 2013;423:39-45.

8. Ertuğrul HD, Uygun ZO. Impedimetric biosensors for label-free and enzymless detection. In: State of the arts in biosensors. Rijeka, Croatia: Intech Rjeka; 2013:179-96 pp.

9. Uygun ZO, Atay S. Bioelectrochemistry Label-free highly sensitive detection of DNA approximate length and concentration by impedimetric CRISPR-dCas9 based biosensor technology. Bioelectrochemistry 2021;140:107812.

10. Uygun ZO, Yeniay L, Girgin Sağın F. CRISPR-dCas9 powered impedimetric biosensor for label-free detection of circulating tumor DNAs. Anal Chim Acta 2020;1121:35-41.

11. Uygun ZO, Ertuğrul Uygun HD. A short footnote: circuit design for faradaic impedimetric sensors and biosensors. Sensor Actuator $B$ Chem 2014;202:448-53.

12. Chang SS. Overview of prostate-specific membrane antigen. Rev Urol 2004;6(10 Suppl):S13-8.

13. Dharmasiri U, Balamurugan S, Adams AA, Okagbare PI, Obubuafo A, Soper SA. Highly efficient capture and enumeration of low abundance prostate cancer cells using prostate-specific membrane antigen aptamers immobilized to a polymeric microfluidic device. Electrophoresis 2009;30:3289-300.

14. Min K, Song KM, Cho M, Chun YS, Shim YB, Ku JK, et al. Simultaneous electrochemical detection of both PSMA (+) and PSMA (-) prostate cancer cells using an RNA/peptide dualaptamer probe. Chem Commun 2010;46:5566-8. 